\title{
RELEVANCE OF INFORMATION AND CONTRACTUAL MODALITY OF AESTHETIC MEDICINE: A COMPARATIVE ANALYSIS BETWEEN SPANISH AND POLISH CASE-LAW
}

\section{Dominika Rymkiewicz*}

\begin{abstract}
Aesthetic medicine has been developing at a fast pace in recent years. It is necessary and ethical for anyone who undergoes any of these treatments to receive complete information on its implementation methods, as well as its consequences and adverse effects. Only once the person who would be affected by these procedures obtains truthful and impartial information, can he or she provide a legally binding consent to undergo a procedure. Thus, the information received by the patient plays a crucial role since it underlies the subject's decision concerning the treatment.
\end{abstract}

Key words: information, consent, contract, medicine.

\section{INTRODUCTION}

Although the practice of beautifying is very common nowadays, we can trace its roots back to antiquity, as far back to ancient Rome ${ }^{1}$. Fast forward to today, we see an exponential increase in uptake of aesthetic medicine as the advancement in technology enabled specialized application to solve purely aesthetic problems ${ }^{2}$. Aesthetic medicine seeks to improve the cosmetic appearance through different surgical and non-surgical procedures

* PhD student, The John Paul II Catholic University of Lublin, Faculty of Law, Canon Law and Administration, dominika.rymkiewicz@wp.pl.

1 Rafał Kubiak. 2016. "Przeprowadzanie zabiegów estetycznych (kosmetycznych)". (In:), Meritum Prawo medyczne, ed. Justyna Zajdel, Warsaw: Wolters Kluwer, 438.

2 Ibidem, pp. 438-440. 
that repair and maintain beauty ${ }^{3}$. Therefore, it is important to note that aesthetic medicine is a procedure that links the transgression of bodily integrity or entry into the human body without disruption of their integrity.

In this paper, I focused my analysis to non- therapeutic aesthetic medicine. In this field, the patient undergoes voluntary change or improvement of his or her body. It is worth referring to the judgements of both the polish and spanish jurisdictions in this case. The jurisprudence of the Civil Chamber of the Spanish Supreme Court assumes that when patients voluntarily submit themselves to a source of risk such as aesthetic medicine, for an improvement of their physical appearances, we are faced with situations where legally protected assets such as health or life can be threatened. In addition, this is an issue and concern as the patient puts himself or herself at risk ${ }^{4}$. Aesthetic medicine does not seek to cure a disease. In other words, the subject who undergoes these treatments is not sick, but rather seeking an improvement of his or her image 5

These kind of treatments or interventions however do not exonerate doctors of their professional duties. They are required to inform potential patients about the consequences of such interventions as well as the different side effects that could occur ${ }^{6}$.

The Spanish Supreme Court states that: "Doctors act on people, with or without alterations in health, and medical intervention is subject to the

3 Jimena Beatriz Manjón Rodríguez, "Configuración jurídica y evolución jurisprudencial en la prestación de servicios de cirugía estética: información, responsabilidad y publicidad", Derecho y Salud, Vol. 23, 1(2013): 223. November 30, 2018 https://dialnet. unirioja.es/servlet/articulo? codigo $=5072446$

4 Judgement of the Supreme Court of 11 December 2001, ref. no. 1193/2001.

5 From my point of view, every subject who undergoes a medical, aesthetic intervention for reparative or beautification purposes is a patient and not a client. The foregoing, given that the active subject, who carrying out the intervention, is a doctor and acts according to his scientific knowledge and on a person who, to a greater or lesser extent, is in a state of inferiority. Therefore the doctors are obliged to act in accordance with the principle primum non nocere. However, a part of the spanish doctrine maintains the opposite, for example: Laura Gázquez Serrano. 2014. “¿La medicina satisfactiva como contrato de obra?”. (In:) Contrato de obra y protección de los consumidores, ed. Klaus Jochen Albiez Dhormann, Madrid: Aranzadi, 729-731.

6 Federico Adan Domenech, "Responsabilidad sanitaria y consentimiento informado”, In: Actualidad Civil, ed. Xavier O`Callaghan Muñoz, Madrid: Wolters Kluwer, 2018. 
random component of the same, therefore, the risks or complications that may arise from the different surgical techniques used are similar in all cases and the failure of the intervention may not be so much in malpractice as in simple biological alterations./.../when it is scientifically recognized that the safety of a result is not possible, since not all individuals react in the same way to the treatments available to current medicine ${ }^{7}$." This statement shows, among other things, that the interventions in this field must be governed by good medical practice and with care since these interventions are all dissimilar. Therefore, both reactions and possible complications might not always be controlled ${ }^{8}$.

\section{RELEVANT INFORMATION}

The acceptance and performance of medical interventions, from my point of view, is based on the consent of the patient to undergo a certain intervention ${ }^{9}$. It is important to note that the patient who grants to the medical professional the consent, immediately approves the intervention in its entirety towards an aspect or specific area of a specific treatment ${ }^{10}$. This consent generates a voluntary acceptance of the risk or risks to which the subject will be submitted to in the intervention. However, it should be noted that medical care is of essential character and this should be linked to the lege artis ${ }^{11}$.

Meticulous information must be provided to the entitled party before obtaining his or her consent. This is to ensure that the patient's decision to undergo the treatment proposed is truly aware and informed because the

7 Judgement of the Supreme Court of 28 June 2013, ref. no. 463/2013; Ana Diaz Martinez, "El resultado o pactado en los tratamientos de medicina estética", Revista Doctrinal Aranzadi Civil-Mercantil, 10 (2011): 27-28.

8 Carlos Sardinero García, Responsabilidad administrativa, civil y penal por falta de información en el ámbito clínico. Criterios indemnizatorios, Valencia: Tirant lo Blanch, 2016, 41-68.

9 Mirosław Nesterowicz, Prawo Medyczne. Komentarze i glosy do orzeczeń sądowych, Warsaw: LexisNexis, 2014, 149.

10 Ibidem, 150.

11 Ibidem, 162. 
lack of information in fact makes the medical act illegitimate. Before performing a procedure, it is important for medical professionals to inform patients about the actual improvement that can be expected, as well as the risks of worsening their current esthetic conditions.

The spanish jurisprudence in one of its judgements affirmed the following: "As for the right of information this one includes the right of the patient to know, on the occasion of any action in the scope of his health, of all the information available on the same/.../. The information must be provided verbally, recording the clinical history [...], the purpose and nature of each intervention, its risks and consequences. This information must be true, and must be communicated to the patient in an understandable and appropriate way to their needs, so that the patient can make decisions regarding their health according to their own free will" ${ }^{\prime 2}$.

For its part, the Polish Supreme Court states that the patient's consent to an aesthetic treatment is maintained only if the patient is fully informed about all the possible effects of the intervention, that is, both more likely and less likely to occur ${ }^{13}$. On the other hand, a doctrinal sector ensures that the consent of the patient when submitting to an intervention linked to the disposition of their legally protected assets excludes the illegality of the intervention, hence the relevance of the information in these processes ${ }^{14}$.

With respect to the nature of the information, I would emphasize that this must be both comprehensive and appropriate in all areas. The information provided to all patients should be detailed, easily understood, precise, and specific to each procedure ${ }^{15}$. This implies that medical professionals will have to communicate this information on a timely

12 Article 4 of Law 41/2002, of 14 November, on patient autonomy and rights and obligations regarding clinical information and documentation.

13 Judgement of the Supreme Court of 5 September 1980, ref. no. II CR 280/80, OSP 1981.

14 Marian Filar, "Odpowiedzialność karna związana z nieterapeutycznymi czynnościami lekarskimi”, Prawo i Medycyna, 5(2010): 69.

15 Jimena Beatriz Manjón Rodríguez, "Configuración jurídica y evolución jurisprudencial en la prestación de servicios de cirugía estética: información, responsabilidad y publicidad", Derecho y Salud, 1(2013): 226-228. 30 November, 2018 https://dialnet. unirioja.es/servlet/articulo? codigo $=5072446$. 
manner and with respective sufficiency. In this way, the patient will be made aware with time in advance of the procedures, risks and consequences, for them to take a reasonable decision without any kind of influence ${ }^{16}$. In this regard, I understand that transcendence of the obligation is not contingent on what the doctor thinks or believes, but what a reasonable person in a patient condition needs to receive objectively from the doctor to make a prudent decision ${ }^{17}$. Subjects who undergo a surgical intervention need to be made aware of the possible frustrations of mediation, that is, of the possibility of the results ${ }^{18}$. Also, they need to be made aware of the hypothetical obstacles or possible negative results that could have temporary or permanent impacts, without assuming these are known variables ${ }^{19}$.

As it is known, the law in certain cases provides some form of legal action for their effectiveness and validity. Regarding the form of consent to carry out the treatments of the field of aesthetic medicine, both Poland and Spain in their respective legislations are pronounced on the written form ad probationem ${ }^{20}$. On several occasions the jurisprudence of both countries has been pronounced in this subject. It must be recognized that the stipulation of a written form without indicating the seriousness of its breach only has the consequences foreseen in the Civil Code ${ }^{21}$. Therefore, it has an evidential nature, having more value in evidentiary procedures and does not deprive consent of legal effectiveness ${ }^{22}$.

16 Rafał Kubiak, Odpowiedzialność karna za wykonywanie zabiegów kosmetycznych. Zagadnienia teorii i praktyki, Cracow: Medycyna Praktyczna, 2012, 228-234.

17 Judgement of the Civil Apeal Court in Poznań of 29 September 2005, ref. no. I ACa 236/05.

18 Judgement of the Supreme Court of 27 September 2010 ref. no. 583/2010.

19 Judgement of the Supreme Court of 29 October 2003, ref. no. III CK 34/02. The patient who accepts the surgical procedure assumes only the risk related to the usual surgical complications. On the contrary, it could not be considered that consent also includes or covers the complications caused by medical malpractice.

20 Judgement of the Supreme Court of 11 April 2006, ref. no. I CSK 191/05; judgement of the Supreme Court of 17 December 2004, ref. no. II CK 303/2004.

21 Act Of 23 April 1964 Civil Code, Journal of Laws from 1964, No.16, item 93 as amended.

22 Judgement of the Supreme Court of 8 July 2010, ref. no. II CSK 117/10. 


\section{CONTRACTUAL MODALITY}

It would seem not entirely undisputed contractual modality of medical interventions since, at present, we do not have unanimity doctrine with respect to the type of contract applied to these interventions in general as well as a determination regarding which of the methods is, so to speak, more convenient. So, we know that both the purpose and the obligations would have different effects depending on the type of contract.

I present below bodies of law that regulate the mentioned aspect. In relation to the rules applicable to these interventions for its part, the article 1544 of the Spanish Civil Code presents the contract to perform a specified task. As is known, in this modality, the professional is obligated to present a result according to what was settled or agreed between the parties before the intervention. Consequently, it is expected that in these contractual modalities not only good faith prevails, but also the appearance of the expected results on the part of the patient ${ }^{23}$. Thus, in a similar direction, the Polish Civil Code in its article 627 states that by the contract to perform a specified task the subject accepts the request, committing to its realization in exchange for remuneration ${ }^{24}$.

Another way to interpret these treatments is in the form of contract of mandate. On this peculiar form of agreement, it can be said that the contract of mandate is, without a doubt, a diligent action contract. For this reason, from the performance of the active subject, that is, on the part of the doctor, will be expected total attention. The lack of criteria to specify what is desired by the active party, leads to the conclusion that its objective consists in carrying out certain activities, and not in reaching a definite outcome ${ }^{25}$. Both contract of mandate and contract to perform a specified task are based on the one hand on the provision of action and on the other hand on paying a stipulated price. The fundamental thing when interpret-

23 Judgement of the Supreme Court of 28 June 1997, ref. no. 580/1997.

24 Act Of 23 April 1964 Civil Code, Journal of Laws from 1964, No.16, item 93 as amended.

25 Pablo Montalvo Revuelta, "Análisis de la postura de nuestros tribunales ante los pleitos relacionados con cirugía plástica y estética”, Revista CESCO de Derecho de Consumo, 8(2013): 197-200. 30 November, 2018 https://revista.uclm.es/index.php/cesco/ article/view/414/0. 
ing these legal actions, is to find the arguments to decide which type of contract should be chosen in these interventions.

In some treatments, obtaining the expected effect is considered as its conclusion. What was measurable in this situation is a result and the contract to perform a specified task is suitable for the contracting of these treatments. In the others, the active subject is obligated to take certain measures to achieve the given objective, but without committing to achieve any specific effect because the result that must be achieved is extremely difficult, and, therefore, the contracts to perform these treatments will have to be seen as contract of mandate ${ }^{26}$.

The existence of a doctor-patient relationship in all the interventions of this kind cannot pass by unnoticed. Whether or not a result is approached that approximates the contract to perform a specified task, the healthcare professional is obligated to try, within its competitive possibilities, to achieve a satisfactory result. Moreover, as it is well known, this should develop its activity under the postulate of the lege artis, which is, according to professional performance ${ }^{27}$. This demonstrates that regardless of the contractual modality with which these interventions are interpreted, healthcare professionals will have to carry out their activities not only in good faith, but also with the special care that requires both knowledge and medical technique ${ }^{28}$.

26 Judgement of the Barcelona Provincial Court of 11 February 2015, ref. no. 50/2015.

27 Judgement of the Madrid Provincial Court of 7 June 2013, ref. no. 263/2013: «Entre los supuestos donde se puede llegar a comprometer un resultado concreto, está la cirugía plástica o estética, reparadora o perceptiva [...] ésta última respecto de un tratamiento de lifting, estiramiento de la piel del rostro y eliminación de papada. En principio, de esta calificación como obligación de resultado, no puede extraerse un régimen general, en materia de carga de la prueba: se mantiene el criterio de la "lex artis ad hoc" (diligencia exigible ex art. 1104 CC, es decir al módulo para la valoración de la negligencia profesional, identificado como "lex artis ad hoc", que constituye el núcleo primordial de la actuación médica, funcionando como rector del acto médico o criterio valorativo de concreción en el caso, es decir, en consideración al caso concreto en que se produce la actuación e intervención médica y las circunstancias en que la misma se desarrolla y tiene lugar, así como las incidencias inesperables en el normal actuar profesional, de forma que tiene en cuenta; las especiales características del autor, de la profesión, de la complejidad y trascendencia vital del paciente [...]"».

28 Katarzyna Golusińska, "Medycyna estetyczna a prawo", In: Nowe procedury medyczne a prawo, ed. Jacek Sobczak, Magdalena Reshef, Toruń: Wydawnictwo Adam Marszałek, 2016, 229. 
Regarding the type of contract, I understand that generally what is agreed upon in aesthetic medicine or in this kind of interventions, has the following characteristics. The contract to perform a specified task is an obligation of stated terms with desired results due to the voluntary connection between the patient and the professional ${ }^{29}$. A result should be achieved which must be present and clearly specified in the contractual terms. As health is not at stake, the information must be as wide as possible in such a way that patients understand and know about the possible secondary and expected effects of the intervention. Thus, the consent must be complete in these interventions ${ }^{30}$.

\section{CONCLUSION}

After analyzing among different sources the jurisprudence related to aesthetic medicine, it should be noted that any treatment of aesthetic medicine applied to a patient without their consent, although it is practiced under the postulate of the lege artis, is illegitimate. The information received by the patient plays a high role in the decision making process. In other words, the information must be considered as a source that guides patients to express to the doctor the consent on the execution of the planned intervention. This information must be present throughout the process, from the planning of its action or prior to the intervention to the time of its realization and after the intervention. Patients at the time of granting the consent to the medical professionals in the aesthetic interventions, voluntary assume the risks and its possible consequences, but the assumption of the risk is subordinated that the information is objective on the part of the medical professional. Therefore, for the information to be useful, it needs to be complete, truthful, and accessible for all patients.

29 Judgement of the Barcelona Provincial Court of 2 March 2005, ref. no. 108/2005; judgement of the Madrid Provincial Court of 30 March 2007, ref. no. 218/2007.

30 Judgement of the Cáceres Provincial Court of 17 April 2002, ref. no. 89/2002. 


\section{REFERENCES}

Adan Domenech, Federico.2018."Responsabilidad sanitaria y consentimiento informado”. In: Actualidad Civil, In: Actualidad Civil, ed. Xavier O Callaghan Muñoz, Madrid: Wolters Kluwer.

Diaz Martinez, Ana. 2011. "El resultado o pactado en los tratamientos de medicina estética”. „Revista Doctrinal Aranzadi Civil-Mercantil” 10: 27-28.

Filar, Marian.2010.”Odpowiedzialność karna związana z nieterapeutycznymi czynnościami lekarskimi”. „Prawo i Medycyna” 5:69.

Golusińska, Katarzyna. 2016. „Medycyna estetyczna a prawo”. In: Nowe procedury medyczne a prawo, ed. Jacek Sobczak, Magdalena Reshef, 229. Toruń: Wydawnictwo Adam Marszałek.

Kubiak, Rafał. 2016. „Przeprowadzanie zabiegów estetycznych (kosmetycznych)”. In: Meritum Prawo medyczne, ed. Justyna Zajdel Justyna, 438-440. Warsaw: Wolters Kluwer.

Kubiak, Rafał. 2012. Odpowiedzialność karna za wykonywanie zabiegów kosmetycznych. Zagadnienia teorii i praktyki. Cracow: Medycyna Praktyczna.

Manjón Rodríguez, Jimena Beatriz. 2013. "Configuración jurídica y evolución jurisprudencial en la prestación de servicios de cirugía estética: información, responsabilidad y publicidad". "Derecho y Salud". 1:223.

Montalvo Revuelta, Pablo. 2013. "Análisis de la postura de nuestros tribunales ante los pleitos relacionados con cirugía plástica y estética”. „Revista CESCO de Derecho de Consumo". 8:197-200.

Nesterowicz, Mirosław. 2014. Prawo Medyczne. Komentarze i glosy do orzeczeń sądowych. Warsaw: LexisNexis.

Sardinero García, Carlos. 2016. Responsabilidad administrativa, civil y penal por falta de información en el ámbito clínico. Criterios indemnizatorios. Valencia: Tirant lo Blanch. 
